\title{
The Role of Journalists in Socializing Money Waqf
}

\section{Yoserizal Saragih}

Universitas Islam Negeri Sumatera Utara, Indonesia

Email: yosesaragih77@gmail.com

\begin{abstract}
:
This study aims to determine the role of journalists in socializing money waqf. This study use qualitative research. The role of journalism is a certain set of behaviors caused by a journalist (journalist) who collects, manages, writes, edits data, so as to produce information or news, whose information is about daily events, periodically using existing mass media facilities. In role theory explains that the role is a point of view insociologyandsocial psychology which assumes that most daily activities are carried out by socially defined categories. Journalism plays an important role in disseminating messages or news to the public with the aim of disseminating something that is considered important to the community. The role of journalism in disseminating cash waqf to the public is as follows:agents of reform, social control tools, public educators, information providers, broadening horizons of thought, focusing attention, fostering aspirations, creating a constructive atmosphere, acting as a bridge, being able to recognize social norms, being able to cultivate tastes andable to change a weak attitude into a stronger attitude.
\end{abstract}

Keywords: journalist; sicializing; waqf

\section{Introduction}

Journalism is an activity that aims to convey messages or news to the public, through media channels. The media used can be in the form of print media, electronic media or the internet. Journalism is related to the science of journalism, namely the science that studies how journalists or journalists work to produce news. Journalism is also a communication activity that uses mass media as a medium in the process of delivering messages or information to audiences that are indirect and one-way. Along with the emergence of technological developments in the era of convergence.

Behind that all journalism has a role in conveying important news for the public to know, for example about news about the discourse on the implementation of cash waqf that will be implemented by the Indonesian government for the community. However, many people are less responsive to the discourse.

For the implementation of a waqf, it is necessary to first understand the issue of the pillars of waqf. In classical books, such as Raudhah at-Thalibin, it is stated that the pillars of waqf are four things, namely waqf (waqf subject), mauquf (waqf object), mauquf alaih (waqf manager), and shighat (contract). Cash waqf is one of the waqf objects which in an Nawawi's view is defined as any certain property that is owned and allows it to be transferred and its benefits are taken. The permissibility of cash/money waqf is also stated by the Hanafi and Maliki schools. Even some scholars of the Shafi'i School also allow cash/money waqf as called Al-Mawardy. 
In Indonesia today, the issue of whether or not cash waqf is acceptable is no longer a problem. It started with the issuance of the MUI fatwa on May 11, 2002. The contents of the MUI fatwa are as follows: 1) Cash waqf (cash waqf / waqf al-nuqud) is a waqf carried out by a person, group of people, institutions or legal entities in the form of cash. ,2) Included in the definition of money are securities, 3) Cash waqf is legal (permissible), 4) Cash waqf may only be channeled and used for things that are permitted according to sharia and 5) The principal value of cash waqf sustainability must be guaranteed, may not be sold, given away and or inherited. The permissibility of cash waqf, according to MUI, does not conflict with the definition of waqf that has been formulated by the majority of scholars by referring to the hadiths about waqf.

However, with all this, some people are not sure about the zakat money that will be planned by the government. Therefore, the role of journalism is very important in providing news on the importance of cash waqf itself. Because some people think that cash waqf is only to fulfill the interests of the government. However, to implement cash waqf in Indonesia, socialization is still very much needed, so that people know the importance of cash waqf itself. Therefore, based on the explanation above, the author wants to describe how the role of journalism is in disseminating cash waqf to the public.

\section{Review of Literature}

\subsection{Understanding the Role of Journalism Performance}

Performance is the achievement of tasks that can be measured against the standards set by each organization (Sultana et al., 2012). According toPawirosumarto et al. (2017)Basically, performance is something that is successfully done or not by employees. Lie et al. (2019)added, performance does not come from the talent or ability of the employee but is the result of the talent and ability itself. From the above understanding, it can be concluded that performance is the result of work that has been successfully carried out by a person and can be measured by the standards that have been set by each organization.

Every employee certainly has different achievements from each other (Zahargier and Balasundaram, 2011). This is due to the placement of employees who are different from each other, depending on their abilities(Yean and Yusof, 2016). This placement is one of the difficult factors by piling up the challenges that each employee has, so that culminates in employee performance (Jacobsen and Bøgh Andersen, 2015). Performance appraisal is one of the functions of human resource management, so it should be done properly. Without performance appraisal, management will certainly find it difficult to determine, for example, how much salary or bonuses, or other appropriate welfare given to employees (Ronny in Edward, 2020).

High employee performance is certainly highly expected by the company, where the more employees have high performance, the company's productivity will increase (Badrianto and Ekhsan, 2020). Akbar (2017) added, to realize this, it is necessary to increase optimal performance by maximizing the potential of the company's resources owned by the company. A role is something that is a part or that holds the main leadership. Role is a form of behavior expected of a person in certain social situations. If what is meant by a role is the behavior expected of a person in a certain status, then role behavior is the actual behavior of the person who performs the role, essentially the role can also be formulated as a series of certain behaviors caused by a certain position. 
Meanwhile, journalism is collecting, processing and disseminating news to the widest possible audience as quickly as possible. The term journalism at this time, may be familiar to the ears. In the Big Indonesian Dictionary it is stated that journalism is the work of collecting, writing, editing and publishing news in newspapers and so on, which relates to journalism and newspapers. Seeing the above understanding, the first point provides an understanding because the first point provides in-depth details starting from the process of gathering news to publishing in newspapers (print media), although in this current era, not only print media but also electronic media are becoming media for journalistic activities.

According to Onong U. Effendi, journalism is managing news from getting material to disseminating it to the public. At first, journalism only managed things that were informative. This is evident in Acta Diurma as the first journalistic product in ancient Rome, when the emperor Julius Caesar came to power. Furthermore, according to Junaedhie that journalism is an activity in communication carried out by broadcasting news or reviews about various things or everyday events that are general and warm, in the fastest possible time. It was further stated that journalism is a professional field that presents information about daily events, periodically using existing mass media facilities. So, the role of journalism is a certain set of behaviors caused by a journalist (journalist) who collects, manages, writes, edits data, so as to produce information or news, whose information is about daily events, periodically using existing mass media facilities.

\subsection{Socialize}

Socialization is an attempt to provide information about a news or news. Socialization can also be referred to as promotion. Promotion occurs because there is also something that must be conveyed, the occurrence of socialization makes the spread of information that is not known by many people and the occurrence of information creates a relationship between the delivery of the message and the recipient of the message. Program socialization is the process of communicating company programs to the community with the aim of providing an introduction and appreciation in a certain environment. Socialization is also one way to exercise social control (social control) if a society wants to function effectively, then community members must behave in accordance with social values and norms that regulate the pattern of life in that society. In socialization, individuals who become members of the community are controlled so that they do not commit deviant behavior. Socialization is forming habits, desires and customs.

In communication activities, socialization involves three major variables that must be considered in order to be successful in its implementation, namely: antecedent variables, process variables, and consequence variables.

a. The antecedent variable indicates that there are several factors that must be considered and observed before carrying out innovation communication activities. These factors relate to the situation and condition of the target audience, both concerning sociodemographic characteristics, psychographic characteristics, as well as real needs and needs felt by the target audience of the socialization program at present and in the future. Identification and scrutiny of these factors are categorized at the stage of preparation for socialization (presocialization stage).

1) Data Collection Data collection, both primary data and secondary data. Primary data collection can be done through survey activities, focus group discussions (FGD). Meanwhile, secondary data collection can be done through a review of written materials, either in the form of documents or other reference materials.

2) Needs analysis The activity is to analyze the data that has been collected, so that real situations, conditions and needs as well as the needs felt by the target audience can be 
identified carefully and accurately. Accuracy in analyzing this need will be very accurate in designing the communication strategy that will be carried out so as to produce the desired effect.

3) Formulation of objectives Determine the final results to be achieved from the socialization activities carried out, it is necessary to formulate what behavior should be pursued after the communication process takes place.

4) Inventory of achievement of goals Inventory of resources needed to achieve these goals. Resources that need to be inventoried include communication resources (communication facilities and infrastructure).

5) Formulation of Strategic Plan Activities to design communication strategies that will be carried out.

6) Formulation of Operational Plan The process of technical planning for the implementation of activities in the field. This stage includes the determination of field personnel, schedule of activities, place of activity, facilities needed, budget, and stages of activities that must be carried out in the field.

7) Evaluation plan formulation The stage of preparing performance indicators to assess program progress, program outcomes, and program impacts. Therefore, it is necessary to prepare evaluation instruments starting from process evaluation or formative evaluation, result evaluation or summative evaluation, and evaluation of program impacts.

b. Consequence variables are factors that arise as a result of decision-making actions to accept or reject innovations, can also be referred to as the post-socialization stage, namely the stage where the entire series of socialization activities is assessed for the level of success, especially to obtain data on the level of achievement of program goals (program results). ) and program impact. Thus, post-socialization activities are filled with activities to carry out results evaluation and impact evaluation, whose instruments refer to instruments that have been designed at the pre-socialization stage. If the decision to accept the innovation (adoption) then the consequences can change real action to continue to adopt and implement it.

\subsection{Zakat Money}

According to the MUI fatwa on Cash Waqf, what is called Cash Waqf (Cash Waqf/Waqf al-Nuqud) is a waqf carried out by a person, group of people, institutions or legal entities in the form of cash. Included in the definition of money are securities. Waqf of movable property in the form of money, hereinafter referred to as cash waqf, is waqf in the form of money that can be managed productively, the results are used for Mauquf alaih. (BWI Regulation number 1 of 2009 concerning Guidelines for the Management and Development of Movable Waqf Assets in the Form of Money). In Law Number 41 of 2004 concerning Waqf Articles 28-31 and Government Regulation Number 42 of 2006 concerning the Implementation of Law Number 41 of 2004 concerning Waqf, Articles 22-27 have regulated the permissible implementation of cash waqf (assets in the form of money).

The legal basis for cash waqf in the Qur'an Surah Al-Hadiid verse 18 which means: "Indeed, those who give charity, both male and female and lend to Allah a good loan, will surely be multiplied (the payment) to them, and for them the reward will be increased. a lot." (Surah Al-Hadid: 18) Surah Ali Imran verse 92 which means: "You never arrive at (perfect) virtue, before you give some of the wealth you love to charity. And whatever you give in charity, Allah knows it." (Surah Ali Imran: 92) Surah Al-Baqarah verse 267 which means: "O you who believe, give alms (in the way of Allah) some of the results of your good efforts and part of what we bring out from the earth for you. And do not choose the bad and give charity from it, but you yourself do not want to take it but by squinting at it. And know that Allah is 
Rich, Praiseworthy." (Surat al-Baqarah: 267) While the hadith that is the evidence is the hadith narrated by Muslim from Abu Hurairah, that the Messenger of Allah said: "A human who dies will stop all the rewards of his deeds, except for three things, namely the reward of charity charity. namely charity whose reward continues to flow which he gives as long as he lives, the reward of knowledge that benefits others that he teaches during his life, and the prayer of pious children." (HR. Muslim). 267) While the hadith that is the proof is the hadith narrated by Muslim originating from Abu Hurairah, that the Messenger of Allah said: "A human who dies will stop all the rewards of his deeds, except for three things, namely the reward for the practice of Sadaqah Jariah, namely alms whose rewards continue to flow. he gave as long as he lived, the reward of knowledge that was beneficial to others which he taught during his life, and the prayer of pious children." (HR. Muslim). 267) While the hadith that is the proof is the hadith narrated by Muslim originating from Abu Hurairah, that the Messenger of Allah said: "A human who dies will stop all the rewards of his deeds, except for three things, namely the reward for the practice of Sadaqah Jariah, namely alms whose rewards continue to flow. he gave as long as he lived, the reward of knowledge that was beneficial to others which he taught during his life, and the prayer of pious children." (HR. Muslim).

Hadith narrated by Bukhari Muslim, which tells that one day Umar's friend came to the Prophet Muhammad SAW to ask for advice about the land he had acquired in Khaibar (a very fertile area in Medina), then he said; O Messenger of Allah, what do you command me about the land? Then the Messenger of Allah said: If you want, you can hold the origin (mainly) and you give charity to him, then Umar gave charity with the land, on the condition that the principal is not sold, not given away and not inherited. While the basis of cash waqf in Indonesia in the form of laws and regulations are: 1) MUI Fatwa of 2002 concerning Cash Waqf 2) Law Number 41 of 2004 concerning Waqf 3) Government Regulation Number 42 of 2006 concerning Implementation of Law Number 41 of 2004 concerning Waqf 4) Regulation of the Minister of Religion Number 4 of 2009 concerning Waqf Administration Money 5) Decree of the Minister of religion number 92-96, the range of Determination of 5 LKS to be LKS PWU 6) BWI Regulation number 1 of 2009 Guidelines for Management and Development of Movable Waqf Assets in the Form of Money.

\section{Results and Discussion}

\subsection{The Phenomenon of Reporting Cash Waqf in Indonesia}

According to the media KOMPAS.com- The government has inaugurated the National Money Waqf Movement (GNWU) and the Sharia Economic Brand at the State Palace, Jakarta, on January 25, 2021. President Joko Widodo, accompanied by Vice President Ma'ruf Amin and Minister of Finance Sri Mulyani as the Chairperson Daily and Secretary of the National Committee for Islamic Economy and Finance (KNEKS) launched GNWU, which is an initiative of the Indonesian Waqf Board (BWI). The government through KNEKS provides support to BWI in developing waqf, especially cash waqf, even better. Head of the Communications and Information Services Bureau of the Ministry of Finance (Kemenkeu) Rahayu Puspasari said KNEKS supports the optimization of waqf in Indonesia by BWI and other nazhir in improving the quality of collection or mobilization, and distribution of benefits to mauquf alaih. The potential for waqf assets annually reaches Rp. 2,000 trillion. Meanwhile, the potential for cash waqf could reach IDR 188 trillion.

According to Merdeka.com media-Inequality in Indonesia has bothered President Joko Widodo (Jokowi). He has made many policies. Various inauguration ceremonies of the construction were attended back and forth. But all is not felt optimal. Instead of increasing the budget, the government actually invites people to do waqf. Mobilizing waqf funds is the 
chosen solutionJokowi. Acting as Chairman of the National Sharia Economic and Finance Committee (KNEKS), the President sees this opportunity as a good choice. Moreover, seeing the data shows the potential for waqf assets per year to reach Rp. 2,000 trillion. Where the potential in the form of cash waqf can penetrate the figure of IDR 188 trillion.

The media world is busy discussing the issue of cash waqf. Especially after President Jokowi launched the National Money Waqf Movement. Special deputy after the Minister of Finance mentioned this in his statement. There were various reactions. There is support. Some refuse. And some are cool. Those who support it argue that this is good because there are alternative sources of funds for national development. Those who refuse to question, waqf are people's funds, they cannot be a source of state fiscal. The cool one thinks, this crowd is only temporary. There will be no follow-up. A week has also been forgotten.

These various reactions are a sign that waqf is becoming a national concern. This is something that has never happened before. From the President to netizens, everyone is talking about waqf. This is good for the introduction of waqf. Especially cash waqf. In the opinion column of the national newspaper KH. Ma'ruf Amin said that waqf has been known only for 3 M; Mosques, Madrasas and Graves. All are fixed assets, immovable. Not many people understand that there is a liquid type of waqf, namely cash waqf. Its use is not limited to the 3 M. Can be used for welfare programs and the benefit of the people. The character of waqf is unique. It must be productive and sustainable. The principal of the waqf property must be maintained. The results of the management that can be allocated. Especially for the public good. Therefore it is called Sadaqah Jariyah. That is charity whose reward continues to flow.

So far, waqf has only been used for the social sector, especially for worship. These include the construction of mosques, madrasas, and tombs. This condition is seenJokowias potential that has not been utilized properly. Even though Muslims in Indonesia have long practiced waqf in their daily life. In addition to the news media about cash waqf above, there are many other mass media news about cash waqf, for example on TV, radio, newspapers, social media and others.

\subsection{Journalistic Role Theory}

Role Theory is a theory which is a combination of various theories, orientations, and disciplines. The term "role" is taken from the world of theater. In theater, an actor must play a certain character and in his position as a character he is expected to behave in a certain way. Role means behavior, act. In the big Indonesian dictionary, role is a set of behaviors that are expected to be possessed by people who are domiciled in society. Role theory is a point of view insociologyandsocial psychologywho assume that most daily activities are played by socially defined categories (eg mother, manager, teacher). Each social role is a set of rights, obligations, expectations, norms, and behavior of a person that must be faced and fulfilled. This model is based on the observation that people act in predictable ways, and that a person's behavior depends on the context, based on social position and other factors.

Literally, journalism comes from the word 'journal' or diary. Journalism means the broadcasting of diaries, news or journalism matters. Dja'far $\mathrm{H}$ Assegaf detailed the definition of journalism as an activity that aims to convey messages or news to the public, through media channels. The media used can be in the form of print media, electronic media or the internet. The press and journalism are two things that are related, but have different meanings. Journalism is a form of work, or the work of journalists. While the press is a medium used by journalists to convey the results of their journalistic work. Journalism plays an important role in disseminating messages or news to the public. In the following, communication experts will 
describe the 13 roles of journalism in society:

a. As a reform agent

b. Entertainer

c. Social control tool

d. Community educator

e. Information Giver

f. Broaden the horizons of thought

g. Focusing

h. Cultivating aspirations

i. Creating a constructive atmosphere

j. As a bridge

k. Able to recognize social norms

1. Able to grow appetite

$\mathrm{m}$. Being able to change a weak attitude into a stronger attitude.

\subsection{The Role of Journalism in Disseminating Cash Waqf}

The importance of the role of journalism in disseminating cash waqf is very influential on the community. Because people really need information and knowledge that can renew their social life. As we know that in various media almost on average discuss government programs about waqf which some people still give a negative response, so for that, all the roles of journalism asconvey messages or news to the public, through media channels. The roles of journalism in disseminating cash waqf to the public are as follows:

1) As a Reform Agent

Through messages or information conveyed to the public, journalism can stimulate, influence, and change behavior and move the community. Be it in a positive way, such as moving the community to be actively involved in development activities, taking beneficial actions for life, implementing social norms, and so on, for example towards cash waqf. So it can be said that journalism has a role as a reforming agent who has great power in the process of social change. But unfortunately, journalism can also be misused to move people to act negatively or destructively. So it needs a good filtering in society, so that destructive journalistic works do not damage the order in society. So,

2) Social Control Tool

Journalism acts as a tool of social control by conveying ideas or opinions related to the interests of the wider community. For example, the government program on cash waqf. Journalism does not only convey or provide information related to an event. Journalists are also obliged to remind, for example, when it is found that there are government policies or other institutions that are seen as contradictory or not in accordance with the interests of the community. Such as informing about the news waqf cash waqf.

3) Community Educator

The role of journalism as a public educator is carried out by presenting a variety of knowledge that is educational and useful for increasing the value of life for its readers. For example, by presenting news about the importance of cash waqf, as well as the benefits of cash waqf itself, journalism that is enlightening and provides new knowledge or insights. Thus, people gain new understanding and understanding of a more advanced life after reading it.

4) Information Giver

The main role of journalism is to provide information. Various journalistic activities that are presented, such as the publication of cash waqf, all related to cash waqf or others, are things that are expected by readers when buying or subscribing to the media. The information presented is not only related to an event, but also in the form of ideas, ideas, opinions, or thoughts that are worthy of being conveyed to the public. 
5) Expanding the Horizon of Thought

Through various information on various news about journalistic cash waqf and then presented to readers through the press; journalism is able to stimulate the decision-making process in society. Journalism also accelerates the transition of society, which initially thought traditional to shift to the thoughts and attitudes of modern society. Or from not yet understanding to understanding.

6) Focusing

The events covered by journalism that are presented to the public can be in the form of information about something specifically discussed, such as cash waqf so that it will be able to stimulate, direct and make the reader focus on it. So, people easily believe in the news presented in various media.

7) Cultivating Aspiration

Journalism has made a major contribution in changing the attitudes and behavior of the community to be responsive to new things, such as news coverage about cash waqf which is programmed by the current government so that this will foster new aspirations in society.

8) Creating a Building Atmosphere

Journalism has a significant role in the process of social change that takes place in society, within a nation. With a variety of information and development ideas that are presented, journalism is able to influence, stimulate, and mobilize the community to be actively involved in development movements or activities in all fields.

9) As a Bridge

Journalism can act as a bridge between the community and the government, or vice versa, namely as a bridge between the government and the community. Journalism is able to develop dialogue on matters related to political issues and the like. such as about the money waqf program made by the government.

10) Able to Introduce Social Norms

Journalism helps development in the field of law by informing about how to avoid crime or crime, as well as about a person's rights and obligations before the law. Likewise with social norms that apply in society.

11)Able to Cultivate Appetite

Journalism can present information that can be used as a tool for community empowerment, to build opinion in the community. such as building public understanding of cash waqf. So that journalism can direct opinions and then foster certain tastes in society.

12)Being able to change a weak attitude into a stronger attitude

Journalism has the power to influence and change behavior so that it can even move people. The same thing can be done by journalism to one's attitude in society. Journalism can change a weak attitude into a stronger one by providing various information and education regarding improving the attitude and mentality of readers.

\section{Conclusion}

The role of journalism is a certain set of behaviors caused by a journalist (journalist) who collects, manages, writes, edits data, so as to produce information or news, whose information is about daily events, periodically using existing mass media facilities. In role theory explains that the role is a point of view insociologyandsocial psychology which assumes that most daily activities are carried out by socially defined categories. Journalism plays an important role in disseminating messages or news to the public with the aim of disseminating something that is considered important to the community. The role of journalism in disseminating cash waqf to the public is as follows:agents of reform, social control tools, public educators, information providers, broadening horizons of thought, focusing attention, 
fostering aspirations, creating a constructive atmosphere, acting as a bridge, being able to recognize social norms, being able to cultivate tastes andable to change a weak attitude into a stronger attitude.

\section{References}

Al- Nawawi. t,th. Raudhah al-Tahlibin wa 'Umdah al-Muftin, jilid II, t.tp.tt.p.

Al-Mawardy, Al-Hawi al-Kabir. (1994). Tahqiq, Mahmud Mukhraji, Beirut Dar al-Fikri.

Departemen Pendidikan Nasional. (2003). Kamus Besar Bahasa Indonesia, Cet. III, Jakarta: Balai Pustaka.

Deviyana Utami Putri. (2010). Strategi Sosialisasi Program Pertamina Pasti Pass Tahun 20072009 ( Study Deskriptif Kualitatif Tentang Strategi Sosialisasi Program Pertamina Pasti Pas PT Pertamina Tahun 2007-2009, (Skripsi: Program S1 Ilmu Komunikasi Universitas Atma Jaya Yogyakarta, Yogyakarta.

Edward, Y and Purba, K. (2020). The Effect Analysis of Emotional Intelligence and Work Environment on Employee Performance with Organizational Commitment as Intervening Variables in PT Berkat Bima Sentana. Budapest International Research and Critics Institute-Journal (BIRCI-Journal). P. 1552-1563.

https://mui.or.id/opini/29604/wakaf-uang-untuk-pembangunan-infrastruktur/, diakses pada: 11 Maret 2021.

https://pakarkomunikasi.com/peran-jurnalistik-dalam-masyarakat, diakses pada: 11 Maret 2021.

https://www.kompas.com/tren/read/2021/01/31/102900465/penjelasan-lengkap-soalwakaf-uang-apa-yang-perlu-kita-pahami-?page=all, diakses pada: 11 maret 2021.

Junaedhie Kurniawan. (1991). Ensiklopedi Pers Indonesia, Jakarta: Gramedia Pustaka Utama.

Junaidi Abdullah, Tata Cara Dan Pengelolaan Wakaf Uang Di Indonesia, Jurnal ZISWAF, Vol. 4, No. 1, Tahun 2017.

Onong U, Effendy. (1984). Dimensi-dimensi komunikasi, Bandung: Alumni.

Peraturan BWI Nomor 1 tahun 2009 tentang Pedoman Pengelolaan dan Pengembangan Harta Benda Wakaf Bergerak Berupa Uang.

Putatgede.Desa.ID, Implemtasi dan Peran Jurnalistik dalam masyarakat, http://putatgede.desa.id/2018/implementasi-dan-peran-jurnalistik-dalammasyarakat/, diakses pada: 10 Maret 2021.

Soerjono Soekanto. (2013). Sosiologi Suatu Pengantar, Jakarta: PT. RajaGrafindo Persada.

Sukanto. (2012). Sosiologi Suatu Pengantar, Jakarta: Rajawali Pers.

Syahrial Syarbaini Rusdiyanta. (2009). Dasar-Dasar Sosiologi, Edisi Pertama, Yogyakarta: Graha Ilmu.

Undang Undang Nomor 41 Tahun 2004 Tentang Wakaf.

W.J.S. Poerwadarminto. (1984). Kamus Umum Bahasa Indonesia, Jakarta: PN Balai Pustaka.

Widjaja. (2008). Pengantar Ilmu Komunikasi, Jakarta: Rieneka Cipta. 